\title{
MOTIF PENGGUNAAN YOUTUBE SEBAGAI MEDIA INFORMASI KECANTIKAN GENERASI MILLENIAL
}

\author{
Zikri Fachrul Nurhadi ${ }^{1}$, Ummu Salamah², Ayudithia Arfinsya Yuniar ${ }^{3}$ \\ ${ }^{1,2,3}$ Program Studi Ilmu Komunikasi, Universitas Garut \\ zikri_fn@uniga.ac.id,
}

Diterima : 30 November 2019; Review : 06 Februari 2020; Direvisi Author : 11 Februari 2020; Terbit : 14 Februari 2020

\begin{abstract}
ABSTRACK
This research is motivated by the rise of teenagers who rely more on the internet, one of which is social media which is now widely accessed by the millennial generation, Youtube. Each Youtube channel is a beauty vlogger how to make-up tutorials for everyday or for certain events and also how to take care of facial skin. Youtube is made a source of information because it displays Youtube which consists of audio visuals that makes it easy for individuals who make it easy to imitate it. The purpose of this thesis is to find new findings (1) Motives (2) Experience and (3) Meanings of Millennial Generation Women who make Youtube as a Media of Beauty Information. This research method uses qualitative methods with qualitative descriptive methods. Data collection techniques carried out through in-depth interviews, participant observation. The researcher determines six research objects to be used as data sources from interviews conducted by purposive sampling. The results of this study indicate that (a) Motive for Millennial generation women using Youtube is to look for make-up tutorials to support development, (b) Motive Because it is more accurate information obtained on Youtube. The results of the findings (c) experience, namely young women can open their own jobs by becoming MUA. In addition, the researchers got the findings (d) The meaning in which YouTube is very helpful for women to find the right make-up and skin care for them.
\end{abstract}

Keywords: Beauty Vlogger; Phenomenology; Millennial Generation; Beauty; Youtube.

\section{PENDAHULUAN}

Perempuan cenderung berkeinginan untuk berpenampilan cantik dan menarik, namun untuk tampil cantik dan menarik di butuhkan perawatan khusus ataupun make up yang dapat mengubah perempuan menjadi lebih cantik. Kehadiran make up didunia ini bagaikan penyelamat yang dapat mengubah perempuan manapun. Tetapi, untuk mengaplikasikan make up ini dibutuhkan keahlian khusus yang kebanyakan orang harus mempelajari dulu teknik-teknik dasar untuk ber make-up. Make up digunakan untuk membuat wajah perempuan menjadi lebih cerah karena dibantu dengan alas bedak atau biasa di sebut dengan foundation. Selain itu, untuk menutupi noda bekas jerawat hanya membutuhkan corrector dan concelear yang dapat menyamarkan noda bekas jerawat. Kebutuhan make up untuk generasi millennial ini sudah dianggap menjadi kebutuhan primer, karena make up dapat menunjang eksistensi diri seorang perempuan (MarComm, 2018).

$$
\text { Informasi mengenai make-up di }
$$
zaman yang modern ini sudah tidak lagi susah untuk di akses, karena banyaknya beauty vlogger atau beauty influencer yang memberikan informasi mengenai kecantikan, baik itu cara make-up dengan macam-macam look ataupun tutorial lainnya, seperti hair do, 
hijab do, skin care routine, yang menyebar informasi tersebut di media social seperti Instagram dan Youtube. Berkembangnya sebuah teknologi menghadirkan media social yang dapat di akses oleh setiap orang yang memiliki fasilitas pendukung seperti, Komputer, Laptop, Gadget dengan sambungan sinyal internet akan bisa dengan mudah untuk mengakses media social. New wave technology merupakan sebuah teknologi yang menghubungkan antar individu yang tidak lagi mengenal jarak, karena dengan new wave technology individu dengan individu lain akan dengan sangat mudah untuk berkomunikasi. Interaksi antar individu semakin mudah dan semakin canggih dikarenakan adanya new wave technology ini. New wave technology didukung oleh perangkat informasi yang semakin canggih sehingga memunculkan revolusi teknologi baru.

Kekuatan utama dari new wave technology ada pada perangkat informasi baru seperti laptop, handphone, serta akses internet yang mudah dan murah. Salah satu media yang disebut dengan new wave technology ini adalah internet. Salah satu layanan yang ada karena akses internet adalah media sosial. Media social sudah memperkuat kedudukan internet sebagai new media communication, dimana jarak seakan tidak lagi terlihat, informasi dan pesan bisa tersampaikan secara global dalam waktu singkat (Ardianto, 2012).
Dewasa ini manusia akan lebih sering berkomunikasi melalui media social menggunakan internet, karena memudahkan berinteraksi dan berkomunikasi tanpa batasan apapun dan tidak mengenal jarak dekat ataupun jauh sekalipun. Pada awal kemunculannya, media social merupakan sebuah layanan jaringan atau situs yang memiliki fasilitas untuk berinetraksi social yang memiliki aktivitas yang sama. Internet merupakan jaringan global yang dapat menghubungkan user di seluruh belahan dunia manapun tanpa dibatasi oleh sekat-sekat geografi, budaya, maupun politik (Akil, 2011).

Berdasarkan temuan penelitian, Salah satu dari sekian banyak media social itu adalah Youtube, Youtube merupakan sebuah aplikasi berbentuk Video Sharing dimana pengguna dapat melihat video dari pengguna lainya, karena pengguna Youtube dapat mengunggah video untuk di nikmati oleh para penggunaan Youtube yang lain atau penonton. Selain itu juga Youtube merupakan situs media social untuk berbagi video yang sangat popular di seluruh dunia. Aplikasi Youtube ini bisa menampilkan beragam macam konten video yang berbeda beda tergantung buatan pengguna yang telah memiliki akun Youtube, termasuk Film pendek, klip film, klip music, selain itu ada pun konten yang amatir seperti Blog video, video original pendek dan video pendidikan. 
Pengguna yang tidak terdaftar akun Youtube dapat melihat atau menonton konten-konten video yang telah di buat dan di unggah oleh pengguna yang telah memiliki akun Youtube atau biasa disebut dengan pemilik Channel Youtube (Palinoan, 2017). Sementara itu, pengguna terdaftar akun Youtube atau yang telah memiliki Channel Youtube dapat mengunggah video dalam jumlah yang tidak terbatas. Peneliti memilih media social berbasis video sharing Youtube, karena di Youtube jumlah pengunggahan satu videonya bisa berdurasi sampai berjam-jam, atau istilahnya tidak ada batasan waktu untuk mengunggah video sehingga akan menjadi efektif jika dijadikan sebagai bahan pencarian informasi, dimana pencari informasi harus mengerti dan memahami bagaimana cara penggunaan Make-up. Sedangkan media social berbasis Video sharing lainnya seperti Instagram dan Facebook hanya memiliki batas waktu setiap unggahan maksimal 3 menit saja. Walaupun antara Instagram, Facebook dan Youtube memiliki kesamaan yang sangat jelas, yaitu sama-sama merupakan media untuk menyalurkan ide-ide kreatif para creative content/influencer yang ada di seluruh dunia. Selain itu juga Youtube bisa dikatakan sebuah media yang paling mudah untuk di akses dimanapun, karena Youtube bisa dilihat melalui handphone, smartphone maupun computer tanpa ada perbedaan, beda hal nya dengan Instagram yang jika dibuka melalui computer akan berbeda tampilannya dengan di handphone/smartphone.

Di Indonesia, Youtube Sangat terkenal dengan jumlah pengguna sudah mencapai 143,26 juta pengguna atau sekitar 54,7 \% dari total jumlah penduduk Indonesia sebesar 265 juta jiwa berdasarkan dara statistic APJII (Asosiasi Penyelenggara Jasa Internet Indonesia) tahun 2018 (https://apjii.or.id). Ini mengacu pada jumlah pengguna Youtube yang aktif per-bulan, termasuk para public figure, atauapun selebritis di Indonesia, mereka melakukan pencitraan untuk mengungkapkan kepada public melalui channel Youtube yang sudah menjadi trend dan banyak digunakan oleh para pencari informasi untuk mengulik sesuatu (https://apjii.or.id). Selain itu juga, Youtube dijadikan sebagai media berkomunikasi menyampaikan suatu informasi atau suatu pesan yang up to date melalui channel Youtube sebagai informasi yang disajikan untuk public, Menurut (Foss, 2009, p. 423) individu diyakini sangat terpengaruh oleh pesan-pesan media, karena media dianggap sangat kuat dalam membentuk opini masyarakat. Pengguna Youtube pun dapat dengan bebas berkomentar terhadap video yang telah diunggah oleh pemilik channel Youtube tersebut. Aktifitas yang berlangganan pada channel youtube seseorang dapat dikatakan sebagai subscriber. 
Biasanya para subscriber ini memberikan komentar dan likes atau dislike pada video yang telah di unggah oleh para pemilik channel Youtube.

\section{Gambar 1}

Tampilan Channel Youtube dari masing-masing pengguna yang memiliki konten berbedabeda (sumber: Youtube 2019)

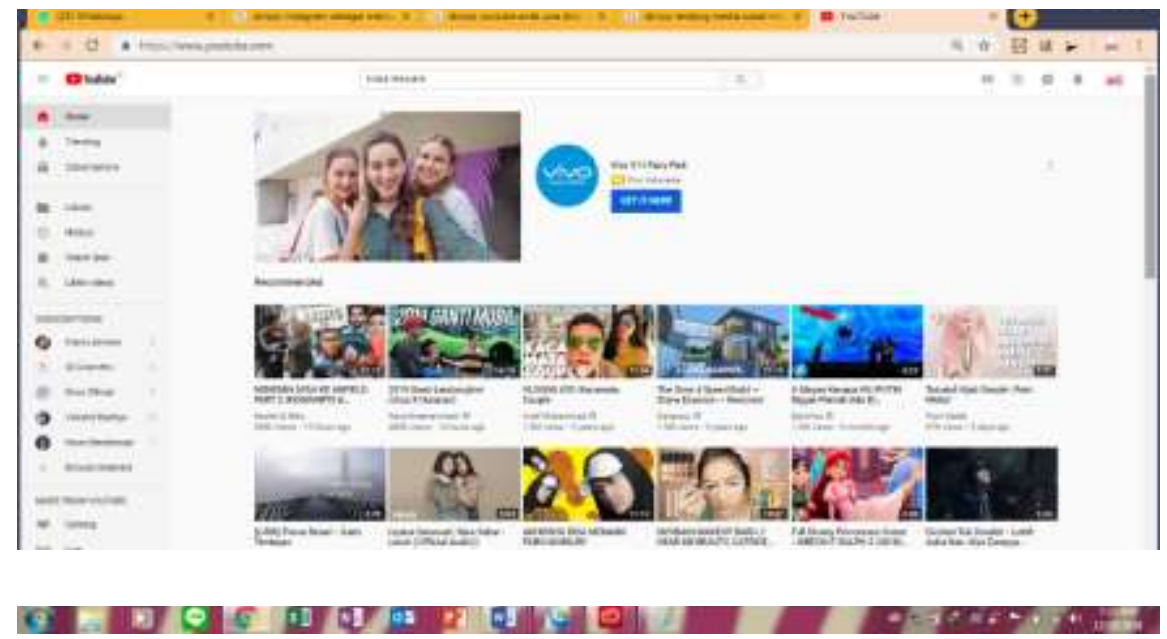

Gambar 2. Tampilan Channel Youtube yang mengunggah video tutorial make-up yang bisa dijadikan sebagai referensi perempuan generasi milenial. (sumber: Youtube 2019)

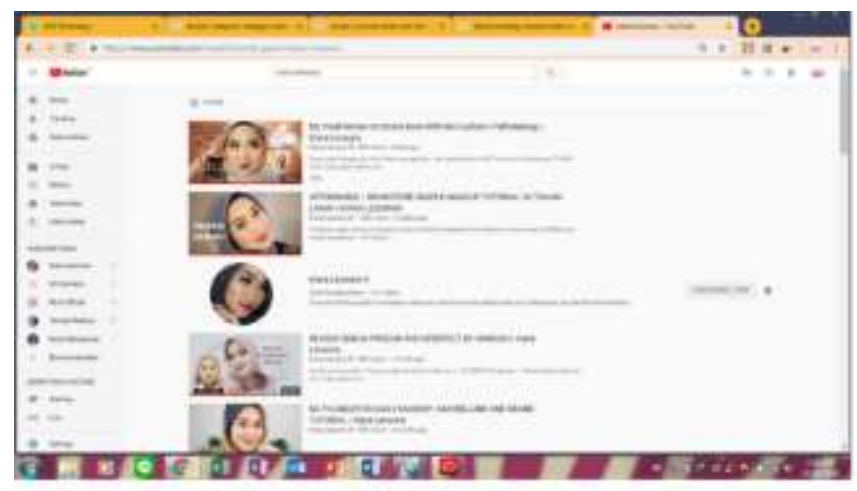

Berdasarkan pada Gambar 2, channel youtube beauty vlogger membuat beragam macam make up looks untuk ditiru oleh para penontonnya. Generasi millennial ini pun lebih banyak mencari informasi apapun yang berpacu pada koneksi internet, salah satu media informasi yang dijadikan sebagai sumber informasi yaitu Youtube, karena Youtube memberikan informasi berupa audio visual yang bisa langsung pencari informasi tersebut melihat bagaimana cara-cara yang dilakukan untuk mencapai Goals tertentu. Banyak nya wanita yang ingin tampil cantik jika ia bepergian ke suatu acara tertentu. Di Youtube, para Beauty Vlogger memberikan informasi berupa bagaimana cara bermake-up dengan look yang berbeda-beda dengan maksud dan tujuan tertentu. Penggunaan 
media sosial ini lebih banyak digunakan untuk menunjukan eksistensi diri yang berlebihan hingga terkadang tidak ada batas kehidupan nyata dan kehidupan didunia maya (Faiqah, 2016). Dengan begitu mudahnya cara untuk mengakses media sosial, maka penggunanya pun menjadi sangat banyak, bukan hanya dari kalangan orang dewasa saja, melainkan merambah ke anak-anak. Saat ini rasanya nyaris tidak ada lagi remaja yang tidak memiliki akun di media social (Baran, 2012). Secara perlahan-lahan kecanggihan teknologi media social yang berkembang saat ini mampu mengubah pandangan remaja tentang bagaimana mereka mnegekspresikan dirinya dan bagaimana dirinya membangun kepribadiannya. Berkembangnya Beauty Vlogger di Indonesia semakin bertambah dari waktu ke waktu, hal ini menjadikan sumber informasi kecantikan para perempuan generasi millennial semakin banyak dan semakin beragam, bahkan para Beauty Vlogger membentuk komunitas yang dinamakan Indo Beauty Vlogger. Komunitas inilah yang mewadahi para Beauty Vlogger Indonesia untuk saling tukar ilmu seputar dunia kecantikan. Dalam komunitas ini berisi para perempuan yang cinta dengan skin care dan make-up. Fenomena ini menjadi sangat menarik saat ada permasalahan terkait Generasi Millenials atau para remaja selalu terpengaruh oleh apa yang disampaikan oleh Beauty Vlogger, baik itu yang menguntungkan ataupun yang merugikan. Masalah dalam penelitian ini yaitu, gaya hidup generasi millennial menjadi lebih hedonism atau boros, karena apa yang mereka lihat dari Youtube selalu membuatnya tertarik dan akan melakukan seperti apa yang Beauty Vlogger lakukan.

Terkait dengan penelitian berjudul "Youtube Sebagai Media Informasi Kecantikan Generasi Millenial" maka peneliti menetapkan Teori fenomenologi sebagai pemandu untuk menemukan fakta dalam penelitian ini. Teori Fenomenologi merupakan cara yang digunakan oleh manusia untuk memahami dunia melalui pengalamannya secara langsung. Fenomenologi membuat pengalaman nyata sebagai data pokok sebuah realitas (Foss, 2009). Penelitian ini dikaji oleh teori Fenomenologi Alfred Schutz dan Edmund Husserl sebagai arahan penelitiannya yang mengkaji secara mendalam tentang motif, pengalaman, serta makna terkait pemanfaatan Youtube sebagai informasi kecantikan generasi millennial. Tujuan utama fenomenologi adalah mempelajari bagaimana fenomena tersebut bernilai atau diterima secara estetis. Fenomneologi mencoba mencari pemahaman bagaimana manusia mengkonstruksi makna dan konsep-konsep yang penting dalam kerangka intersubjektivitas (Kuswarno, 2009). 
Berdasarkan pemaparan yang telah peneliti jelaskan, maka kajian penelitian tentang Youtube Sebagai Media Informasi Kecantikan Generasi Millenial ini relevan dengan penelitian yang dilakukan oleh Fatty Faiqah, dkk (2016) dengan judul "Youtube Sebagai Sarana Komunikasi Bagi Komunitas Makassar Vidgram” jurnal komunikasi Kareba Vol.5 No.2 Juli-Desember 2016. Penelitian ini bertujuan untuk mencari tahu bagaimana kelebihan, kekurangan Youtube yang dijadikan sebagai media komunikasi komunitas MakasarVidgram. Penelitian ini menggunakan metode kualitatif dan menggunakan teori New Media sebagai landasan penelitian. Hasil penelitian ini membuktikan bahwa pemanfaatan Youtube sebagai sarana komunikasi komunitas MakassarVidgram ini cukup membantu. Penelitian ini menemukan bahwa Youtube mempunyai karakteristik nilai yang efektif dan efisien untuk dijadikan sarana komunikasi oleh para anggota MakassarVidgram berdasarkan masing-masing kebutuhan pengguna. Respon dari para informan mengenai kelebihan dan kekurangan Youtube sebagai sarana komunikasi lebih banyak menyondong kepada kelebihannya saja, hal ini yang membuat Youtube ternilai sangat efektif dan efisien sebagai sarana komunikasi bagi komunitas MakassarVidgram.
Alasan peneliti tertarik mengambil judul Youtube Sebagai Media Informasi Kecantikan Generasi Millenial ini dikarenakan, banyaknya perempuan yang menginginkan dirinya tampil cantik untuk menunjukan eksistensi diri mereka di dunia maya (media social) ataupun di dunia nyata. Informasi kecantikan yang didapatkan oleh para remaja melalui Media Youtube ini, bagaimana dampak dan keuntungan yang didapatkan oleh para perempuan yang ingin ber make up dibandingkan harus membayar mahal-mahal untuk MUA (Make Up Artist). Dari permasalahan tersebut, Maka dari itu, peneliti tertarik untuk meneliti dan membahas permasalahan tersebut menjadi sebuah Skripsi dengan judul "Youtube Sebagai Media Informasi Kecantikan Generasi Millenial”. Berdasarkan pemaparan yang telah dijelaskan, maka yang menjadi fokus masalah pada penelitian ini adalah Bagaimana motif, pengalaman dan makna yang mendasari Generasi Millennial menjadikan Youtube Sebagai Media Informasi Kecantikan Generasi Millenial? Tujuan penelitian ini adalah untuk menjelaskan tentang Motif, pengalaman dan makna Perempuan Generasi Millenial yang menjadikan Youtube Sebagai Media Informasi Kecantikan. 


\section{METODE PENELITIAN}

Metode penelitian ini menggunakan metode deskriptif dengan pendekatan kualitatif. Informan peneliti adalah seseorang yang memiliki informasi (data) banyak mengenai objek yang sedang diteliti, diminta informasi mengenai objek penelitian tersebut. Informan berfungsi sebagai umpan balik yang memiliki data penelitian dalam ruang cross check data. Dalam penelitian ini, peneliti menggunakan teknik purposive sampling. Penelitian fenomenologi melalui wawancara dengan informan yang jumlahnya berkisar antara 5-25 orang. Peneiliti diharuskan menggunakan refleksi diri dalam mengembangkan penjelasannya secara artistic (Kuswarno, 2009). Maka, pada penelitian terkait dengan judul Youtube sebagai media informasi kecantikan generasi millennial.
Peneliti menetapkan informan sebanyak 6 orang. Yaitu perempuan yang berumur 18 -25 tahun dan selalu mencari informasi mengenai kecantikan melalu Youtube di kota Bandung. Strategi ini menghendaki informan dipilih berdasarkan pertimbangan peneliti dengan tujuan tertentu. Dijadikan informan dengan pertimbangan bahwa merekalah yang paling mengetahui informasi yang akan diteliti. Informan dalam penelitian ini adalah orangorang yang sadar dengan perkembangan teknologi dan memanfaatkannya sehingga digunakan setiap hari. Dengan beberapa kriteria yang sudah ditentukan oleh peneliti berfungsi agar peneliti mendapatkan jawaban yang bervariasi dari setiap informan yang di wawancara.

\section{Tabel 1}

Informan Penelitian

\begin{tabular}{clcc}
\hline No & \multicolumn{1}{c}{ Nama } & Usia & Pekerjaan \\
\hline 1. & Astri Lestari & 21 tahun & Mahasiswa \\
2. & Tri Ayuning Tyas & 19 tahun & Mahasiswa \\
3. & Sarah Tahany & 18 tahun & Pelajar \\
4. & Rayhan Pahlawati & 21 tahun & Pegawai non-cpns \\
5. & Bella Berliana & 22 tahun & Job Seeker \\
6. & Ghea Shebika & 22 tahun & Frelancer \\
\hline
\end{tabular}

Sumber : (Olah Data Peneliti, 2019)

Tabel 1 menjelaskan tentang beberapa nama informan yang akan diwawancara pada penelitian ini. Beberapa kriteria ini dipilih oleh peneliti karena dianggap memenuhi syarat dan mempunyai pengetahuan dan informasi sesuai dengan judul penelitian mengenai Youtube Sebagai sarana Informasi. Peneliti mendapatkan informan menggunakan media social Instagram, lalu peneliti mencari followers pada Instagram Beauty Vlogger yang berasal dari kota Bandung, lalu peneliti mengirimkan Direct Message kepada para 
informan untuk dijadikan sebagai informan penelitian ini. Untuk beberapa informan (Astri Tri Lestari dan Ghea Shebika) peneliti bertemu dengan mereka di toko Make-up di kota Bandung yang bernama Makeuppucino lalu peneliti berkata bahwa peneliti akan melakukan penelitian terkait informasi mengenai Make-up yang didapatkan dari Youtube, dan setelah bertanya-tanya ternyata Astri dan Ghea termasuk kepada kriteria peneliti untuk dijadikan informan. Pada penelitian ini orang yang akan dijadikan sebagai informan tidak memperlihatkan diri bahwa mereka adalah yang mencari dan mendapatkan infromasi mengenai kecantikan dari media social Youtube, berikut adalah beberapa kriteria informan oleh peneliti: (1)
Wanita dewasa berumur 18 tahun sampai 25 tahun berdomisili di kota Bandung, Tertarik mencari informasi kecantikan melalui Youtube, (3) Mengakses media social youtube sebagai media untuk mencari mengenai informasi kecantikan minimal 1 minggu 1 kali, (4) Menggunakan aplikasi Youtube, (5) Sadar dengan perkembangan teknologi yang modern, (6) Mempunyai Smartphone, (7) Tertarik untuk membel Brand yang ditampilkan di Youtube, (8) Informan terdiri dari berbagai elemen lapisan diantara lain: Mahasiswa, Wiraswasta dan Pelajar, (9) Sudah berpengalaman mencari informasi terkait kecantikan melalui Media Sosial Youtube Minimal 1 tahun

Tabel 2

Narasumber Untuk Proses Triangulasi

\begin{tabular}{|l|l|l|l|}
\hline No & \multicolumn{1}{|c|}{ Nama } & \multicolumn{1}{|c|}{ Usia } & \multicolumn{1}{c|}{ Pekerjaan } \\
\hline 1. & Pradesti Kemala Putri & 23 tahun & Model Freelancer di kota Bandung \\
\hline 2. & Oschillatoria Dwi & 22 tahun & $\begin{array}{l}\text { Beauty Vlogger yang memiliki channel dan } \\
\text { aktif di Youtube (influencer make up) }\end{array}$ \\
\hline
\end{tabular}

Sumber : (Olah Data Peneliti, 2019)

Tabel 2 menjelaskan tentang narasumber yang akan diwawancara untuk penelitian ini. Narasumber. Beberapa kriteria ini dipilih oleh peneliti karena untuk mencocokan data antara hasil wawancara narasumber, dengan proses triangulasi orang yang ahli pada bidangnya. Peneliti menetapkan 2 narasumber untuk proses triangulasi yang berkriteria sebagai berikut :
(1) Memiliki pemahaman yang mendalam mengenai Make-up, (2) Memiliki pengalaman di bidang per-make up-an minimal 2 tahun, (3) Bekerja di ruanglingkup Make-up (baik itu sampingan atau pekerjaan tetap), Memahami tentang kesehatan kulit wajah. Narasumber pertama untuk proses triangulasi adalah Pradesti Kemala Putri, ia model freelancer yang ada di kota Bandung yang 
melakukan pekerjaan nya untuk di make up oleh MUA (Make up Artist) dan telah memiliki pengalaman yang banyak di dunia kecantikan, karena ia seorang model yang sudah memiliki jam terbang yang tinggi, bahkan telah mengisi acara Launching produk handphone VIVO V11 PRO yang ditayangkan di stasiun TV swasta. Sedangkan narasumber kedua ada Oschilatoria Dwi, ia merupakan salah satu beauty vlogger dari kota Bandung yang memiliki channel Youtube dan konten youtubenya membahasan mengenai kecantikan dan memberikan informasi mengenai make-up. Selain ia adalah Beauty Vlogger ia pun bekerja sebagai makeup artist (MUA) yang telah berpengalaman di dunia kecantikan dan sudah dipercaya oleh para client nya terkait make-up yang dihasilkan nya.

Sedangkan teknik pengumpilan data pada penelitian ini adalah wawancara mendalam dan observasi non partisipan. Adapun langkah-langkah peneliti dalam melakukan wawancara mendalam, antara lain : (a) Menentukan informan, (b) Melakukan

\section{HASIL DAN PEMBAHASAN}

Motif Perempuan Generasi Millenial Yang Menjadikan Youtube Sebagai Media Informasi Kecantikan

Dalam hal ini, motif informan pada saat melakukan pencarian informasi mengenai hal-hal yang menyangkut kecantikan, informan memiliki motif yang berbeda-beda, komunikasi terlebih dahulu dengan informan, (c) Memperkenalkan diri dan menyampaikan tujuan kepada informan, (d) Menentukan jadwal wawancara dengan menyesuaikan jadwal kosong informan, (e) Menjelaskan maksud dan tujuan pertanyaan yang diberikan untuk gambaran sebelum menjawab pertanyaan. Adapun langkah-langkah peneliti dalam melakukan observasi partisipan pada peneliti yang berjudul Youtube Sebagai Media Informasi kecantikan Generasi Millenial, antara lain: (1) Melakukan komunikasi terlebih dahulu dengan informan, (2) Menentukan penjadwalan khusus untuk melakukan kegiatan pengamatan,

Observasi penelitian pertama dilakukan saat proses wawancara mengenai profesi informan, (4) Peneliti ikut serta kegiatan informan guna mengetahui bagaimana informan menangkap apa yang di tayangkan di Youtube mengenai informasi kecantikan, (5) Peneliti akan mengamati seberapa banyak alat make-up dan skincare yang dimiliki oleh informan.

tergantung pada kebutuhan make-up dan skincare yang sedang dibutuhkan oleh para informan.

\section{Motif Untuk}

Schutz mencontohkan, jika seorang membuka payung ketika hujan turun, maka motif pertama (motif-untuk) akan berupa 
pernyataan "menjaga baju agar tetap kering". Selanjutnya menjelaskan bahwa melihat kedepam pada masa yang akan datang (looking forward into the future) merupakan hal yang esensial bagi konsep tindakan atau action (handle). Berkaitan dengan motif pengguna media social Youtube sebagai media informasi kecantikan yang digunakan oleh para generasi millennial di kota Bandung pun mengungkapkan alasan yang berbedabeda seperti yang diungkapkan oleh Tyas (Informan 2), ia mengungkapkan motifnya ketika melakukan pencarian informasi mengenai kecantikan melalui media social Youtube.

\begin{abstract}
"soalnya kan kalo kecantikan tuh perlu ya, kayak ngerawat mukanya terus cara penggunaan Make-upnya itu kan penting, misalkan dari Youtube itu udah dikasih tau tutorial cara pake nya kayak gimana, bentuk produknya kayak apa, jadi lebih jelas aja gitu. Hehe. Kalo youtube tuh menurut aku sumber informasi nya akurat dan lebih banyak juga kayak dari Beauty Influencernya gitu kan banyak banget dan beauty vloggernya gitukan banyak daripada di Instagram itu reviewnya rata-rata dari endorse jadi nggak honest review banget gitu, jadi mending di Youtube sih kata aku mah.”
\end{abstract}

Tyas menuturkan bahwa dengan adanya Youtube bisa dapat lebih mengetahui informasi yang banyak mengenai kecantikan, salah satunya yaitu, bagaimana cara penggunaan Make-up yang benar, dan bagaimana baiknya pengaruh review yang di berikan oleh para beauty vlogger atau beauty Influencer itu sangat membantu ketika Tyas ingin mengetahui bagaimana bentuk suatu produk make-up yang sebelumnya ia ingin beli. Adapun pernyataan lain yang dilontarkan oleh Hany (Informan 3), mengenai motifnya menggunakan Youtube sebagai Media informasi kecantikan karena looks make up di youtube lebih variatif:

\begin{abstract}
"Karena menurut saya, media social yang bisa dibilang akurat itu adalah Youtube terus videonya lebih banyak dan variatif macammacam looks make-up juga banyak di youtube gitu. Youtube itu beda aja gitu menariknya, konten-kontennya juga menarik, soalnya kayak youtube sekarang kan lagi boomingboomingnya, apa ya... banyak banget yang bisa kita cari dari hal kecil yang sesulit apapun pasti bakalan ada gitu di Youtube".
\end{abstract}

\section{Motif Karena}

Sementara itu, suatu tindakan dapat berupa "tindakan yang sedang berlangsung" (the action in progress) dan "tindakan yang terlengkap" (the complected act) dengan melihat pengalaman dan pengetahuan sebelumnya tentang bagaimana akibatnya pada baju jika hujan tanpa payung, misalnya digambarkan sebagai pernyataan "agar baju tidak basah" (Kuswarno, 2009). Dengan demikian tujuan dan tindakan memiliki elemen ke masa depan (futurity) dan elemen ke masa lalu (pastness) untuk menggambarkan bahwa tujuan suatu tindakan social seprang cukup komplek, Schutz meminjam istilah basaha, dengan menyebutkan in the future prefect tense (modo futuriexcati). Selanjutnya berkaitan dengan motif karena yang dilakukan perempuan generasi millennial di kota 
Bandung mencari informasi mengenai kecantikan di media social Youtube. Adapun menurut tanggapan dari Hany (Informan 3) mengungkapkan tentang motifnya menggunakan media social Youtube karena durasi video di youtube lebih panjang dibandingkan dengan media social Instagram, dan tertarik mencari informasi terkait kecantikan, karena ingin menjadi lebih cantic ketika pengetahuan tentang make up nya semakin baik:

\begin{abstract}
"yaa kalo misalnya youtube kan udah jelas berbentuk video eeh durasinya juga lebih panjang gak kayak Instagram yang durasinya cuman 15 detik terus kayak cuman beberapa menit doang gitu gak kayak youtube yang bisa berjam-jam bahkan hehehe...sebenernya kebutuhan sih yak karena ketertarikan liat orang lain apa ya ber makeup kayak gitu, apalagi misalnya ada waktu kosong gitu lebih apaya lebih tertarik aja liat beauty vlogger gitu , dan sudah menjadi kebutuhan juga".
\end{abstract}

Hany dengan Rayhan (Informan 4) memiliki motif yang sama terkaitt mengapa mereka menggunakan Youtube sebagai media informasi kecantikan, karena Youtube memiliki durasi penayangan video yang cukup lama, selain itu juga menurut Rayhan (informan 4) di Youtube juga memudahkan apa yang ingin ia cari dengan hanya mengetik kata kunci saja:

“ yang membuat tertarik karena mencarinya lebih mudah. Karena awalnya kan suka makeup tuh waktu nyari-nyari buat wisuda kayak gimana nih cara mau make-up tapi nyari informasi nya gampang, kayak liat youtube kan tinggal search aja apa yang kita mau dan lebih komunikatif aja gitu si orang yang beauty vloggenrnya dan kitatuh gampang gitu nyerap informasinya lebih nyata, ya kalo youtube sih sebenernya lebih ke durasi ya, kalo social media lain kan mungkin misalnya dibandingin sama Instagram kan paling cuman videonya cuman satu menit kan terus ada yang di swipe-swipw gitu kan jadi males nontonnya, kalo youtube kan durasinya lebih lama, jadi lebih enak aja nonton nya, lebih jelas juga penyampaian informasinya, gak setengah setengah lah kalo di Instagram kan kayak cuplikan cuplikannya aja"

Rayhan menuturkan tujuan nya bahwa mencari informasi mengenai kecantikan melalu media social youtube itu lebih mudah dicari, karena ia hanya cukup dengan memasukan word atau kata kunci saja, semua informasi mengenai kecantikan yang ia butuhkan akan muncul. Selain itu Rayhan menuturkan bahwa, Beauty Vlogger menyampaikan informasi dengan sangat baik, dan bisa diterima maksud dan tujuan beauty vlogger tersebut.

Berikutnya pernyataan yang diungkapkan oleh Tyas (Informan 2), dalam tujuannya menggunakan media social Youtube untuk mencari infornasi mengenai kecantikan sebagai berikut:

"hmm.. soalnya kalo kecantikan tuh perlu ya, kayak ngerawat mukanya, atau cara penggunaan make-up nya itukan penting, kalo dari youtube tuh kayak udah dikasih tau tutorial cara pakai nya kayak gimana, bentuk produknya yang dipake juga diliatin jadi lebih jelas. youtube tuh menurut aku lebih akurat informasinya, sumber informasi nya lebih banyak kayak dari beauty influencernya kayak gitukan banyak banget,reviewnya beautybeauty vlogger gitukan banyak juga, daripada di Instagram cuman review biasa, kadang juga dari endorse, bukan honest review gitu, jadi mending di youtube sih kata akumah" 


\section{Pengalaman Menggunakan Media Sosial Youtube Sebagai Informasi Kecantikan}

Pengalaman komunikasi yang

dianalisis oleh peneliti adalah pengalaman bagaimana setiap perempuan generasi millennial yang memilih youtube sebagai media informasi kecantikan yang mereka pilih. Juga bagaimana para informan mendapatkan informasi mengenai kecantikan melalui media social Youtube . Pengalaman para informan pun berbeda-beda setelah menggunakan youtube untuk mencari informasi mengenai kecantikan, informan mengungkapkan alasan nya mengapa ia lebih memilih media social youtube untuk mencari informasi mengenai kecantikan dibandingkan dengan media social lainnya. Seperti yang di ungkapkan oleh Tyas (Informan 2) ia menggunakan media social Youtube karena menurutnya, di Youtube informasinya lebih jelas :

"kan kalo misalkan sekarang jaman udah makin canggih kan, jadi youtube mah pasti di butuhin bukan tentang apaya..make up atau skincare gitu aja tapi tentang tutorial masak tuh di youtube tuh lebih jelas gitu informasinya, kayak kalo misalkan nih kallo liat dari youtube, kita tau takaran-takarannya daripada ngeliat di internet, bisa masuk ke dunia yang lebih luas daripada di tv, lebih mending di youtube gitu lah daripada di tv"

Tyas mengungkapkan bahwa pengalamannya menggunakan Youtube itu sangatlah membantunya untuk melakukan aktifitas apapun selain dari tutorial make-up. Tyas mengungkapkan bahwa di youtube pun bisa dicari bagaimana cara memasak yang benar, takaran yang pas pun bisa dilihat. Tyas juga mengunkapkan bahwa media social youtube sangat membantunya untu menggunaakan make-up dibandingkan dengan harus les make-up atau menyewa jasa MUA hanya untuk menggunakan make-up:

"yaa cukup puas sih dibandigin sama harus les
make-up gitu dengan budget yang gede lebih
dari sejuta keatas kan untuk make-up class
gitu, sedangkan kita cuman modal quota
doang udah bisa belajar make-up sampe bisa
terampil lah, sampe bisa bener-bener make-up
in orang tuh udah jadi achievement banget
gitu."
Tyas mengungkapkan bahwa ia menggunakan youtube sebagai media informasi kecantikan adalah untuk belajar menggunakan make-up sendiri, tanpa harus dibantu oleh tangan MUA (Make Up Artist).

Adapun pengalaman dari Rayhan (Informan 4), ia menceritakan bagaimana pengalaman nya mencari informasi mengenai kecantikan melalui media social youtube:

"ya kalo dibilang puas sih puas banget cuman karna yang namanya belajar kadang apa yang kita udah hasilin tuh ternyata massih bisa lebih bagus lagi, karena waktu itu kan pas pertama buka youtube tentang beauty karena waktu mau wisuda itu kan bener bener masih 0 lah, pengetahuan make up bener bener masih 0 , terus mulai cari cari di youtube dan memberanikan diri make up untuk wisuda dan dibandingin sekarang yang mungkin hampir mau setaun setelah wisuda tuh kayak, yaampun make up aku waktu wisuda tuh jelek banget hehehe. Ngerti gak sih.......jadi make up nya gimana ya, kadang pengen make up ngeliat tutorial tuh buat dirumah aja kalo keluar tuh kurang percaya diri gitu, jadi kadang kalo misalnya ke undangan nih misalnya padahal udah ada tutorial make up 
ke undangan tapi gak akan semenor itu karena mungkin ada apasih namanya, masing masing punya kesukaan masing-masing soalnya make upnya kayak gimana gimana cuman kalo liat youtube emang suka di praktekin tapi yang cuman dirumah aja, tapi kalo buat ke undangan ya natural natural aja, gak tebel tebel juga"

Rayhan mengungkap kan bahwa ia merasa puas telah berhasil menggunakan make-up sendiri pada saat akan wisuda tahun 2018 lalu, dengan bantuan dari beauty vlogger dan Rayhan juga mengunkapkan bahwa semakin ia belajar, semakin ia bisa lebih baik lagi untuk menggunakan make-up. Sama hal nya pengalaman yang di utarakan oleh Hany (Informan 3), Hany menuturkan bahwa dirinya sangat puas dan merasa bangga ketika berhasil menggunakan make-up dengan tangan sendiri:

"bangga sih ya, pasti itu udah bangga banget beda aja gitu hasil sendiri hasil dibikinin oranglain tuh pasti beda gitu. Ya karena apaya...bisa dibilang kayak kepuasan tersendiri gitu, kayak pake tangan kita sendiri gitu, terus ya apa yang kita liat oranglain bisa kayak ginituh bagus apalgi kita sendiri yang bisa bikin kayak gitu."

Ungkapan dari Hany (Informan 3) ini memperjelas bahwa ia memiliki kepuasan tersendiri hanya dengan melihat dari salah satu channel youtube beauty vlogger saja.

Makna Menggunakan Media Sosial
Youtube Sebagai Informasi Kecantikan
Dalam memaknai Youtube
mebagai
(Informan $\quad$ 4) mengungkapkan makna

menggunakan Youtube sebagai media informasi kecantikan:

\begin{abstract}
"sangat membantu sih, karena kalo gak dari youtube kalo sejujurnya saya bukan orang yang suka ke mall, dan nanya ke mbak mbaknya nanya ini gimana bagusnya gimana bukan orang yang seperti itu, jadi youtube sangatlah membantu bagi orang orang yang seperti saya yang gak pd ke mbaknya, kadang suka malu aduh jerawatan kadang suka ada mbak yang ngomongnya *teeh ini kalo jerawatan mening pake ini* sakithati gitu, kalo misalnya di youtube kan kalopun dia ngomongin jerawatan tapi gak ada yang denger gitu kita doang yang nonton, walaupun dia ngomongin tentang jerawat misalnya, kalo si mbakmbaknya misalnya suka ngomong *teeh kalo kayak gini ya mendingan pake ini* walaupun itu promosi tapi kan itu kesannya kayak kamu ngeledek aku jerawatan....gitu, jadi youtube tuh bener bener ngebantu bangetlah buat aku yang gak pd sama nanya nanya ke mbak mbaknya, terus kan kita kalo nanya nanya gak beli, malu juga. Kalo di youtube kan mau nanya sambil coment atau sambil nyari beauty vlogger lain kan gampang gitu, gak ribet juga"

Selain Rayhan, Ghea (Informan 6) pun mengutarakan makna nya menonton Youtube untuk mencari informasi mengenai
\end{abstract} kecantikan:

"kayak ya orang gampang ngeakses gitu, ya
menurut aku banyak orang yang belajar make
up bayar mahal mahal gitukan. Nah sekarang
di youtube tuh bisa"

Ghea menyatakan bahwa Youtube sangat mudah di akses oleh semua orang, dan beuaty vlogger sangat memberikan ilmu untuk para perempuan belajar make-up dengan tidak mengeluarkan uang privat atau kursus make-up, itu bisa membuat para mahasiswa menjadi lebih hemat. 
Pengungkapan makna yang di tuturkan oleh Tyas (Infroman 1) ialah, menurutnya mengetahui ilmu tentang kesehatan kulit wajah dan merias wajah adalah utnuk membuat seorang wanita menjadi lebih percaya diri:

"hmm makna nya sih ya menurut aku sendiri, make up tuh kan bukan buat kira terlihat cantic buat ketemu siapapun tapi kayak buat lebih biar pd, kalo missal kan jalan atau kemana, kayak misalkan aku ya yang pertamanya gak pd buat pake make-up semenjak tau cara-cara make-up dan make up tuh ternyata berdampak positif buat aku, makin nambah apaya kepercayaan diri gitu, meskipun emang ga setiap hari make up full tebel gitu, tapi pasti adalah satu dua make-up yang dipake setiap hari”

Ungkapan makna yang di tuturkan oleh Tyas berbeda dengan apa yang dirasakan oleh Hany, ia sebenarnya menyadari bahwa dengan menonton channel youtube tersebut, memaksa dirinya untuk berubah akrena oranglain terlihat lebih menarik:

\begin{abstract}
"sebenernya ada manfaatnya ada buruknya juga gitu, ya misalkan kayak keseringan juga kan gak baik buat diri kita. Apalagi kan anak sekolah kan gak harus pake yang kayak gitu, cuman ya karena udah ketertarikan sama oranglain, jadi ngikutin dan dipake buat sehari-hari gitu."
\end{abstract}

Adapun tanggapan dari Astri, mengenai makna menggunakan youtube sebagai media informasi kecantikan adalah untuk membantu orang orang yang ingin membeli make up atau skincare:

$$
\begin{aligned}
& \text { "memudahkan orang-orang dalam } \\
& \text { membeli produk make up atau } \\
& \text { skincare, soalnya sekalin } \\
& \text { memperkenalkan make up/skincare } \\
& \text { mereka juga mereview produk tersebut } \\
& \text { bagus atau tidakna sehingga orang- } \\
& \text { orang bisa memilah dan tidak } \\
& \text { menyesal beli produk tersebut." }
\end{aligned}
$$

Astri memiliki anggapan bahwa Youtube sangat membantu untuk para perempuan memilih produk make up apa yang layak dibeli atau biasa disebut "worth to buy”, banyak beauty vlogger yang membuat review make up dan skincare sejujur mungkin, bahkan jika beuaty vlogger merasa make up tersebut tidak layak untuk dibeli, mereka akan mengatakan yang sebenarnya di ikuti dengan alasannya. Berdasarkan hasil observasi, peneliti mendapatkan temuan para perempuam generasi millennial di kota Bandung, sangat terbantu dengan adanya informasi mengenai konten make-up yang dibuat oleh para beauty vlogger dan beauty influencer di media social Youtube, karena youtube menampilkan tampilan berbentuk audio visual, sehingga para perempuan generasi millennial mudah menirukan bagaimana tutorial make-up atau skincare yang dibutuhkannya.

\section{Pembahasan}

Pada bagian ini, peneliti akan mempertegas bahasan penelitian berdasarkan hasil temuan yang di peroleh dari lapangan, 
kemudian di perkuat oleh teori yang telah peneliti paparkan pada pembahasan. Salah satu kekuatan media sosial yang paling berpengaruh yaitu pada saat beauty vlogger membuat honest review mengenai brand makeup tersebut yang membuat produk makeup tersebut banyak di minati oleh para perempuan yang tertarik dengan review yang di buat oleh beauty vlogger. Selain itu juga manfaat dari banyak nya informasi mengenai kecantikan ini adalah para perempuan bisa menciptakan pekerjaan nya sendiri dengan menjadi MUA atau Make Up Artis.

Melalui pendekatan ini, peneliti akan mengungkapkan apa saja hal-hal yang peneliti temukan di lapangan, yang mencakup media social youtube sebagai media informasi kecantikan bagi perempuan generasi millennial. Berdasarkan hasil wawancara peneliti yang dilakukan dengan ke enam informan, peneliti mendapatkan hasil mengenai "motif" perempuan generasi millennial di kota Bandung yang menjadikan youtube sebagai informasi mengenai kecantikan. Hasil temuan ini sesuai dengan teori yang digunakan oleh peneliti dalam penelitian ini, yaitu teori fenomenologi. Yang dimana “motif”mengacu pada semua penggerak, alasan, atau dorongan yang ada dalam diri manusia yang menyebabkan ia melakukan sesuatu.

Salah satu yang menjadi kegiatan para pengguna Youtube khususnya perempuan generasi millennial adalah untuk menemukan informasi mengenai make up dan skincare yang ingin mereka ketahui. Dengan melihat fenomena yang menarik untuk di perbincangkan, pada kenyataan nya memang banyak pengguna youtube yang menggunakan youtube sebagai pelengkap kebutuhan nya dalam kehidupans sehari-hari. Dalam menonton tayangan youtube, para perempuan generasi millennial di kota Bandung pasti memiliki tujuan tersendiri. Pendekatan fenomenologi yang dingkapkan oleh Shutz adalah melihat manusia dari pengalaman subjektifnya (Kuswarno, 2009). Pada hakikatnya, perempuan ingin berpenampilan cantic dan menarik, maka dari itu perempuan tersebut harus bisa merawat diri mereka dan mengcover semua yang ada kekurangan di wajahnya menggunakan make-up. Menggunakan make up tidaklah mudah dan sangat dibutuhkan keahlian khusus, di jaman era globalisasi ini, informasi mengenai make up sudah bisa di dapatkan melalui jaringan internet, salah satunya bisa didaptkan melalui youtube. Selain itu, di youtube informasinya sangatlah lengkap dan memudahkan para pencari informasi untuk mendapatkan informasi yang mereka inginkan. Youtube di anggap sudah menjadi konsumsi sehari-hari para remaja, khususnya perempuan, karena di youtube informasi mengenai kecantikan apapun itu mudah dicarinya, video di youtube lebih variatif dan konten konten nya dibuat 
semenarik mungkin. Pada tahun 2017 sampai sekarang, youtube masih menjadi trend atau hal yang booming karena hal apapun yang ingin dicari di youtube dapat ditemukan, dimulai dari hal mudah hingga hal-hal yang sulit. Dalam channel channel youtube beauty vlogger, para beauty vlogger menyampaikan hal-hal yang menarik, seperti looks make-up terbaru dan looks make-up natural untuk sehari-hari. Tak jarang juga para beauty vlogger memberikan tutorial looks make-up bold atau tampilan make-up tebal untuk digunakan ke acara-acara yang formal. Dalam youtube, para pemepuan generasi millennial di kota Bandung mendapatkan hal-hal baru untuk menunjang penampilan (kecantikan) mereka, karena informasi kecantikan di youtube sangtalah variatif. Selain untuk mencari infromasi mengenai kecantikan, para perempuan generasi millennial pun mengakses media social Youtube untuk mengisi waktu luang para perempuan ketika sedang tidak melakukan kegiatan apapun.

Mencari review make up dan skincare menjadi salah satu tujuan para perempuan generasi millennial di kota Bandung menonton Youtube. Karena, menurut hasil wawancara dengan informan, informasi di youtube sangat variatif mengenai review make-up. Review make-up sangatlah penting sebelum konsumen membeli make up tersebut. Konten yang membuat review makeup dan skincare dianggap sangat membantu para perempuan generasi millennial untuk menemukan make-up yang cocok untuk kulit mereka, bahkan dengan warna kulit mereka sekalipun. Review make-up itu beragam macamnya, dimulai dari make-up A sampai make-up Z dapat di cari di youtube. Biasanya para beauty vlogger mereview make up sesuai dengan ekspetasi dan apa yang mereka rasakan, tidak di lebih-lebihkan atau bahkan di kurang-kurangi.

Bahkan ada beberapa informan yang influence terbesar untuk membeli produk make-up adalah karena "teracuni" atau terpengaruhi oleh review di youtube. Para beauty vlogger membuat review sangat spesifik, mulai dari tekstur, warna (shade), kepekaan terhadap kulit (pigmented), bahkan sampai memberi tahu, berapa lama make-up tersebut akan tahan di kulit wajah kita. Tetapi balik lagi kepada cara seseorang memakai produk make-up tersebut, jadi banyak yang memakai produk yang sama tetapi hasilnya berbeda. Kata "bagus", "enak", :terbaik", "cocok" itu sangatlah relative, karena tujuan para beauty vlogger membuat konten review sebuah produk make-up atau skincare adalah untuk berbagi kepada khalayak mengenai pendapat mereka sendiri, bukan untuk mempunyai opini yang sama dengan oranglain. Selain itu, tujuan para perempuan generasi millennial di kota Bandung yang ingin mencari review make-up adalah mencari referensi yang seluas-luasnya agar 
mendapatkan gambaran mengenai produk make-up atau skincare dari berbagai sudut pandang.

Setiap perempuan pasti ingin terlihat cantic dan menjadi percaya diri ketika berada dilingkungan laur rumah dengan cara menggunakan make-up. Para perempuan generasi millennial di kota Bandung, memanfaat media social youtube untuk mencari tutorial make-up, dari mulai make-up yang natural sampai make-up yang tebal. Tutorial yang di berikan oleh para beauty vlogger sangat sederhana, sehingga para pemula yang baru menggunakan make-up bisa dengan mudah untuk meniru. Make-up memang dibuthkan oleh para perempuan, misalnya make up yang mendasar seperti lip balm dan lipstick diperlukan agar bibir terliihat terawat, selain itu jika wajah perempuan tersebut kusam atau memiliki noda noda hitam, mereka bisa menyamarkan nya dengan menggunakan concelear (Widyawati, 2017).

Kini, make-up semakin di minati oleh para perempuan, apalagi dikalangan remaja, kemanapun mereka pergi selalu tidak lupa untuk menggunakan make-up. Sekarang make-up sudah seolah olah menjadi kebutuhan pokok para perempuan khususnya bagi remaja. Make-up merupakan hal wajib yang harus dimiliki, baik itu pelembab, concelear, foundation, cc cream, bb cream, dd cream, bb cushion, blush on, mascara, bedak, dan sebagainya. Motif 'karena' mengacu langsung pada peristiwa masa lalu sebagai sebab-sebab dari tindakan. Dengan kata lain motif karena (because motiv) merupakan hal-hal yang melatarbelakangi seseorang melakukan tindakan tertentu berdasarkan dari pengalaman masa lalunya. Masing-masing informan memiliki motif 'karena' yang berbeda-beda. Durasi video di youtube yang lebih panjang di bandingkan dengan media social lainnya seperti Instagram membuat para perempuan generasi millennial lebih tertarik untuk mencari informasi kecantikan melalui media social youtube, tidak seperti Instagram yang hanya memiliki waktu penayangan video hanay 15 detik (insta story), dan 3 menit (feeds). Perempuan generasi millennial di kota Bandung lebih tertarik melihat review dari media social youtube dibandingkan dengan media social lainnya, seperti Instagram. Kebanyakan di Instagram para beauty influencer membuat review yang di bayar oleh produk make-up atau skincare tersebut atau yang biasa dengan paid endorsement. Jika beauty influencer tersebut sudah menerima bayarannya, maka ia harus memberikan review yang baik, bahkan sampai melebih-lebihkan untuk menaikan target penjualan produk tersebut.

Media social youtube salah satu situs web video sharing, yang dimana penggunanya dapat menonton, membagikan video dan saling berbalas komentar. Youtube 
kini kian menjadi semakin booming, karena perempuan generasi millennial tidak lagi tertarik untuk menghabiskan waktu mempelajari tata cara menggunakan make-up dengan cara membaca, namun lebih tertarik melihat dan mendengar sekaligus untuk dapat mempraktekan apa yang mereka lihat. Dengan munculnya berbagai macam video tutorial make-up, tutorial tersebut langsung dapat ditiru oleh penontonnya. Pengalaman para perempuan generasi millennial di kota Bandung yang telah menggunakan Youtube sebagai media informasi kecantikan. Pengalaman ini merupakan sebuah kejadian yang pernah mereka alami, dan dijalani oleh para informandan serta di rasakan oleh mereka. Peneliti mencoba menjelaskan konsep atau fenomena pengalaman yang di dasari oleh kesadaran yang terjadi pada beberapa informan dalam melakukan situasi yang sebelumnya pernah dialami, sehingga tidak ada batasan dalam memaknai atau memahami fenomena yang terjadi, peneliti dapat menganalisis data yang diperoleh dari hasil wawancara serta observasi langsung dengan pada informan. Pengalaman memungkinkan seseorang menjadi lebih tahu dan hasil dari mengetahui ini kemudian menjadi sebuah pengetahuan yang dapat digunakan atau di implementasikan di masa depan.

Makna selalu mencakup banyaknya aspek pemahaman yang secara bersama dimiliki para komunikator. Pembentukan makna adalah berfikir sesuai dengan kemampuan atau kapasitas kognitif yang didalamnya terdapat informasi yang dimilikinya (Prianto, 2014). Dari hasil wawancara dengan ke enam informan, ratarata informan memiliki makna yang berbedabeda, dimana informan mencari informasi mengenai kecantikan melalui media social youtube mempunya makna untuk tampil menjadi lebih cantic dan percaya diri. Hasil pembahasan makna yang didapatkan oleh peneliti yang peneliti temukan di lapangan adalah, youtube memiliki makna sebagai media yang mempermudah para manusia khususnya generasi millennial untuk menemukan informasi-informasi terbaru. Selain itu, makna yang didapat juga adalah para remaja perempuan menajdi lebih kreatif dan percaya diri untuk menggunakan make up pada saat ia beraktifitas dilingkungan luar, makna yang lain yang didapatkan oleh peneliti ketika melakukan wawancara yaitu, salah satu informan mengatakan bahwa youtube dapat membantu ia ketika ia tidak tahu bagaimana cara menggunakan sebauh produk atau alat make-up, dengan melihat youtube ia menjadi tahu, karena di youtube penyampaian informasi nya sangat jelas dan berbentuk audio visual sehingga mudah untuk ditiru. Salah satu informan juga mengatakan bahwa youtube di jaman sekarang sangat berpengaruh bagi dunia kecantikan, banyak 
perempuan yang merasakan hal ini. Makna dari lain menggunakan youtube untuk informasi kecantikan adalah beberapa perempuan yang tidak tertarik untuk menggunakan make-up dan skincare, setelah menonton youtube perempuan tersebut menjadi lebih aware dengan penampilannya, bahkan salah satu informan mengatakan bahwa lama-lama menyukai make-up dan ingin menjadi beauty vlogger (Nasrullah, 2016).

Selain hal-hal positif yang di temukan oleh peneliti dilapangan, peneliti pun menemukan hal-hal negative yang berkaitan dengan media sosial youtube sebagai media informasi kecantikan generasi milenial. Hal negative tersebut yakni adalah remaja perempuan di kota Bandung cenderung menjadi memiliki gaya hidup yang hedonism dan konsumtif, faktor ini timbul karena adanya ketertarikan para perempuan untuk meniru hal-hal ataupun gaya hidup beauty vlogger panutan nya. Seperti, Make up yang di gunakan oleh beauty vlogger para remaja tersebut tertarik untuk membilnya padahal ia tidak membutuhkan nya itulah hal yang membuat para remaja rela untuk mengluarkan uang lebih untuk keingan nya dibandingkan kebutuhan nya. Selain dari hasil wawancara dengan informan, peneliti pun juga melakukan wawancara dengan narasumber, guna untuk memeriksa keabsahan data yang didapatkan di lapangan dengan melakukan wawancara dengan informan terkait interpretasi seseorang. Triangulasi sumber dalam penelitian ini adalah Oscillatoria Dwi, ia merupakan seorang yang berprofesi sebagai MUA (Make Up Artist) yang sekaligus juga menjadi beauty vlogger, channel youtube Oscillatoria Dwi ini adalah, "ochidwi", ia mengunggah video-video mengenai tutorial make-up dan skincare routine. Selain Ochi, triangulasi sumber yang di lakukan peneliti yaitu melakukan wawancara dengan Pradesti atau yang akrab disebut Desti, ia merupakan model freelancer di kota Bandung yang sudah bekerja di lingkup fashion termasuk make-up, jadi ia sangat mengerti bagaimana bekerja di ruang lingkup per make-upan. Adapun pertanyaan mengenai triangulasi sumber terkait motif informan yang mencari informasi kecantikan melalui media social youtube untuk membuat dirinya menjadi lebih cantic dan percaya diri, yang secara tidak langsung membuat eksistensi dirinya menjadi naik. Disini triangulasi sumber mengatakan bahwa youtube sangat efektif untuk pembelajaran mengenai kecantikan, yang didalamnya memuat ilmu-ilmu atau teknik menggunakan make-up, hal ini merupakan hal yang positif untuk Para perempuan, menurut triangulasi sumber ia memiliki kemampuan make-up dan tertarik untuk membuat channel youtube sebagai beauty vlogger karena ia ingin membantu para perempuan lainnya untuk meniru ilmu-ilmu make-up yang bisa 
lakukan, dan selain itu juga menjadi beauty vlogger dapat menghasilkan uang yang didapat dari Goggle Adsence (Ramadanty, 2014). Selain itu triangulasi sumber mengungkapkan makna mencari informasi kecantikan melalui media sosial youtube ini adalah untuk membantu para perempuan yang ingin mendapatkan informasi kecantikan

\section{PENUTUP}

Berdasarkan hasil penelitian dan pembahasan, maka yang menjadi kesimpulan penelitian ini adalah:

a. Motif youtube sebagai media informasi kecantikan generasi millenial ini bahwa pemanfaatan youtube sebagai media informasi kecantikan generasi millennial cukup efektif, dikarenakan hasil durasi video dapat diunggah di Youtube lebih panjang durasinya dibandingkan media social lainnya, informasi yang didapatkan melalui media social Youtube memiliki informasi yang akurat, karena para beauty influencer selalu memberikan review terkait produk atau brand make-up sesuai dengan realita yang terjadi, atau biasa disebut dengan honest review.

\section{DAFTAR PUSTAKA}

Akil, M. A. (2011). Teknologi Informasi dan Komunikasi ; tinjauan sistem, perangkat, jaringan, dan dampak. Makassar: Alauddin University Press.

Ardianto, E., Komala, L., \& Karlinah, S. (2012). Komunikasi Massa Suatu tetapi tidak mau membuang-buang uang yang banyak atau waktu yang banyak, karena untuk mencari informasi mengenai kecantikan melalui media social youtube ini, hanya dibutuhkan quota dan waktu kosong saja. Tidak seperti belajar kursus make-up yang bisa sampai mengeluarkan uang berjuta-juta hanya untuk belajar make-up. b. Pengalaman perempuan generasi millennial menjadi lebih boros karena selalu membeli hal-hal yang tidak dibutuhkan, di sampin itu pengalam positif juga menuntut lebih memahami mengenai kesehatan kulit wajah, hal positive lainnya yaitu sebagai sarana belajar menggunakan make-up yang akan menjadi lapangan pekerjaan untuk dirinya sendiri sebagai MUA (Make-Up Artist).

c. Makna youtube sebagai media informasi kecantikan generasi millenial untuk mencari review mengenai make-up maupun skincare, lebih mempermudah para perempuan dibandingkan harus bertanya-tanya kepada SPG dari suatu brand make-up atau skincare yang akan di belinya.

Pengantar Edisi Revisi. Bandung: Simbiosa Rekatama Media.

Baran, S. J. (2012). Pengantar Komunikasi Massa Jilid 2 Edisi 5 (Melek Media dan Budaya). Bandung: Erlangga.

Faiqah, F., Najib, M., \& Amir, A. S. (JuliDesember 2016). Youtube Sebagai Sarana Komunikasi Bagi Komunitas 
Makassar Vidgram. Jurnal Vol.5 No.2 , 2016.

Foss, S. W. (2009). Theories Of Human Communication. Jakarta: Salemba.

Kuswarno, E. (2009). Metodologi Penelitian Komunikasi Fenomenologi. Bandung: Widya Padjajaran.

MarComm, M. (2018). MILLENIALS. Jakarta: Fanatasious x Loveable.

Muliyawan, D., \& Suriana, N. (2013). A-Z Tentang Kosmetik. Jakarta: PT. Elex Media Komputindo.

Nasrullah, R. (2016). Media Sosial Perspektif Komunikasi, Budaya dan Sosioteknologi. Bandung: Simbiosa Rekatama.
Palinoan, I. Y. (2017). Dampak Tayangan Vlog di Youtube Terhadap Gaya Hedonis Siswa SMA Kristen Sunodia. Jurnal Vol.5 No. 2 Tahun 2017, 215225.

Prianto, J. (2014). CANTIK Panduan Lengkap Merawat Kulit Wajah. Jakarta: PT. Gramedia Pustaka Utama.

Ramadanty, S. (2014). Penggunaan Komunikasi Fatis dalam Pengelolaan Hubungan di Tempat Kerja . Jurnal Ilmu Komunikasi Volume. 5 No.1 , 3.

Widyawati Mp, 2017. Cyber Bullying di Media Sosial Youtube (Analisis Interaksi Sosial Laurentius Rando Terhadap Hatters). Fakultas Dakwah dan Komunikasi Universitas Islam Negri Alauddin, Makassar. 